\title{
Soil Microbiological Attributes Under Ecological Restoration Technologies in Subtropical Forest
}

\author{
Graciele Ferreira da Rosa ${ }^{1}$ \\ https://orcid.org/0000-0002-3306-6386
}

Carlos Alberto Casali ${ }^{1 *}$

https://orcid.org/0000-0001-6094-8889

Fernando Campanha Bechara ${ }^{1}$

https://orcid.org/0000-0001-7573-2124

Jéssica Maiara Viceli ${ }^{1}$

https://orcid.org/0000-0002-1407-7004

Flavia Lima Moreira ${ }^{1}$

https://orcid.org/0000-0001-6408-7959

\author{
André Francisco Ferreira ${ }^{1}$ \\ https://orcid.org/0000-0002-6324-3347
}

Isabella Araújo Peppe ${ }^{1}$

https://orcid.org/0000-0002-3907-1004

Amanda Cristina Beal Acosta ${ }^{1}$

https://orcid.org/0000-0001-9778-5972

Letícia de Alcântara Dôres ${ }^{1}$

https://orcid.org/0000-0002-3103-8138

Bruna Larissa Feix ${ }^{1}$

https://orcid.org/0000-0003-2811-4651

\section{Bruna Schneider Guimarães ${ }^{1}$}

https://orcid.org/0000-0001-9902-0148

1 Universidade Tecnológica Federal do Paraná, Campus Dois Vizinhos, Dois Vizinhos, Paraná, Brazil;

Received: 2019.10.28; Accepted: 2020.03.02.

*Correspondence: carloscasali@utfpr.edu.br; Tel.: +55-46-3536-8408

\section{HIGHLIGHTS}

- Soil microbiological attributes are sensitive to evaluate soil quality in ecological restoration.

- The recovery of soil microbiology is slow in areas under ecological restoration.

- Changes in forest cover interfere in soil microbiological activity.

Abstract: To accelerate the recovery of degraded environments, it is necessary to use ecological restoration techniques, which require validation according to the ecosystem conditions where are implemented. This work aimed to evaluate soil microbiological attributes under different ecological restoration technologies in a subtropical forest. The study was conducted at UTFPR-DV, southwest of Paraná, in an ecotone between Mixed Ombrophilous Forest and Semideciduous Seasonal Forest and on an Oxisol. In December 2010, a tillage area of at least 17 years old was isolated and the passive restoration, tree planting and nucleation treatments were installed in 40x54 m plots and four replications. In November 2018 the soil was sampled in these plots and in a native forest area as a reference. There were calculated soil organic carbon content (OCC) and microbiological attributes such as microbial biomass $\mathrm{N}$ and $\mathrm{C}$ ( $\mathrm{N}_{\text {MIC }}$ and $\mathrm{C}_{\text {MIC }}$ ), basal respiration, fungal spore content and the metabolic $\left(\mathrm{qCO}_{2}\right)$ and microbial quotient $(\mathrm{MICq})$. It can be concluded that nucleation technology can restore soil microbiological attributes but has not yet reached the conditions of a natural environment. Passive restoration is not a good technology for restoring soil microbiological attributes. The higher contents of $\mathrm{C}_{\text {MIC, }} \mathrm{N}_{\mathrm{MIC}}$, OCC, MICq and fungal spores in the soil under native forest compared to 
ecological restoration technologies indicate that eight years of adoption of these techniques have not yet been enough to fully recover soil microbiological activity.

Keywords: degraded areas; ecologic succession; soil microbiology.

\section{INTRODUCTION}

Anthropic action, mainly for the expansion of the agricultural sector, contributes to the reduction of tropical and subtropical forests in Brazil. The State of Paraná has predominantly the Atlantic Forest Biome, which is fragmented into small forest nuclei without connection between themselves and its original characteristics being altered, making flora and fauna genic flow each time more difficult.

According to Wadt [1] such changes promote the loss of the area productive capacity, generating a degraded system and compromising vegetation and soil quality. Natural systems are closely related to vegetation cover and soil attributes, as fundamental ecological processes, such as nutrient cycling, occur in them [2].

Before recovering an area, it is necessary to know how regeneration occurs in those environments that have been subjected to different disturbances, whether natural or anthropic [3], once they present different levels of intensity, duration and resilience [4]. The recovery of degraded areas is a multi-step procedure that needs to be developed simultaneously in order to restore its productive capacity [5].

Regardless of the degradation level of an ecosystem, it is necessary to adopt recovery techniques [1], which can be as simple as passive or natural regeneration, which consists in isolating the degraded area and regenerating it through its own seed bank [6], complex as nucleation, which consists of the use of different biological dissemination techniques allocated in the same area, such as a bank or rain of seeds, perches and wildlife shelters [7], in addition to traditional tree planting, with appropriate spacing and species for each location.

To validate ecological restoration techniques, in addition to assessing vegetation, it is also important to identify their effects on soil chemical, physical and microbiological attributes, as they are essential inputs to promote sustainability and conservation [2]. The physical, chemical and biological attributes of the soil are interrelated, controlling the processes and aspects related to their variation. Conservationist practices improve the quality of the environment, contributing to the development of soil microorganisms, maintaining or increasing organic matter, promoting nutrients increase, while structurally and physically protect the soil [8].

Forest soil is a favorable environment for the development of microorganisms, which can be used as biotic factors to observe the balance or alteration of forest ecosystems [9]. For Peña [9], in the early succession phase, the soil has little productive capacity reflecting low microbial activity. Thus, as the quality of the area improves, the more satisfactory microbiological results become. Therefore, the study aimed to evaluate soil microbiological attributes under different technologies of ecological restoration in subtropical forest in southwestern Paraná, Brazil.

\section{MATERIAL AND METHODS}

The study area is located at the Universidade Tecnológica Federal do Paraná, campus Dois Vizinhos (UTFPR-DV) $\left(25^{\circ} 41^{\prime} 40,47^{\prime \prime} \mathrm{S}\right.$ and $\left.53^{\circ} 06^{\prime} 12,82^{\prime \prime} \mathrm{W}\right)$, with average altitude of $502 \mathrm{~m}$ and humid subtropical climate (Cfa), with no defined dry season, with average annual temperatures between $19{ }^{\circ} \mathrm{C}$ and $20^{\circ} \mathrm{C}$, and frequent frosts [10]. The soil is an Oxisol and the vegetation is an ecotone between Mixed Ombrophilous Forest and Seasonal Semideciduous Forest.

The experimental area was used with annual crops from 1993 to 2005 and perennial pasture between 2006 and 2008. In May 2009, oat (Avena strigosa) was sown, which was harvested in October of the same year, leaving the area fallow until October 2010, when it was cleared and isolated from disturbing factors.

In December 2010 three treatments were implemented: passive restoration; tree planting under fill line and diversity and nucleation. Each treatment has four replications with $40 \times 54 \mathrm{~m}\left(2,160 \mathrm{~m}^{2}\right)$ plots, subdivided into 24 subplots of $9 \times 10 \mathrm{~m}\left(910 \mathrm{~m}^{2}\right)$. As reference area we used a native forest bordering the experimental area.

Passive regeneration consisted of isolating the area for monitoring ecological succession without anthropic intervention. Planting native seedlings under fill and diversity lines [11] consisted of planting 30-50 $\mathrm{cm}$ tall seedlings, interspersing the fill species (10 fast growing and dense canopy pioneer species) with diversity species (60 non-pioneer species), with a total of 1,440 seedlings of 70 regional species in the four experimental plots. 
The nucleation techniques [12-13] implanted were: artificial bird perches; artificial shelters for the attraction of terrestrial fauna; planting of seedling from bank and rain of forest seeds; planting of trees in Anderson groups of five seedlings, spaced $1 \times 1 \mathrm{~m}$ (cross-shaped) where the four lateral plants were shaded (12 pioneer species) and the central plant was shaded (24 non-pioneer species); $3 \times 4$ m core covered with cowpea (Cajanus cajan); and planting of bromeliads (Bromelia antiacantha) in Anderson groups of five seedlings, spaced $0.5 \times 0.5 \mathrm{~m}$ (cross-shaped). The set of techniques were implemented in $3 \times 40 \mathrm{~m}$ strips, where the cleaning was done through mowing and chemical weeding. Within this treatment were used the same tree species as the tree planting treatment, except for the maricá (Mimosa bimucronata).

In November 2018, 8 years after the implementation of the treatments, the soil was sampled in the $0-5$, 5-10 and 0-20 cm layers with six sub samples per plot that were joined to form a composite sample. For the microbial analyses, only samples from the $0-5 \mathrm{~cm}$ layer were used, which were sieved in a $2.0 \mathrm{~mm}$ mesh, standardized to $35 \%$ humidity and stored in a refrigerator to preserve microbial activity. For the chemical analysis, the layers 0-5, 5-10 and 10-20 were used, being air dried, ground and sieved in $2.0 \mathrm{~mm}$ mesh.

The chemical characterization of the soil followed the methodology of Tedesco [14] for $\mathrm{pH}-\mathrm{H}_{2} \mathrm{O}, \mathrm{pH}-\mathrm{SMP}$ (buffer $\mathrm{pH} 7,5$ ), available phosphorus (P) and potassium (K) contents, while for the soil organic matter (SOM) wet combustion methodology was used according to Yeomans and Bremner [15], obtaining first the total organic carbon content (OCC), which was multiplied by the factor 1.724 (Table 1).

Microbial carbon and nitrogen contents $\left(\mathrm{C}_{\text {MIC }}\right.$ and $\mathrm{N}_{\text {MIC }}$ ) were obtained by the fumigation extraction method as described in Silva [16-17]. For this, $50 \mathrm{~g}$ of soil was weighed in duplicate, two samples fumigated with chloroform and two not fumigated for 24 hours. Thereafter, $50 \mathrm{~mL}$ of $0.5 \mathrm{M}$ Potassium Sulphate $\left(\mathrm{K}_{2} \mathrm{SO}_{4}\right)$ was added and stirred on horizontal shaker for $30 \mathrm{~min}$ at $150 \mathrm{rpm}$, followed by decantation for 60 minutes and filtered in paper filter. $\mathrm{C}_{\mathrm{MIC}}$ was obtained by sulfochromic digestion and titration with ammonium ferrous sulphate, according to Vance [18]. $\mathrm{N}_{\text {MIC }}$ was measured by digesting the extract in a digester block with $\mathrm{H}_{2} \mathrm{SO}_{4}$ and $\mathrm{H}_{2} \mathrm{O}_{2}$ and distilling in in Kjeldahl distillator with boric acid indicator.

Table 1- Soil chemical attributes in 0-5, 5-10 e 10-20 cm layers after eight years of implantation of the ecological restoration techniques passive restoration, tree planting and nucleation, besides native forest area as reference.

\begin{tabular}{|c|c|c|c|c|c|}
\hline \multirow{2}{*}{$\begin{array}{l}\text { Chemical } \\
\text { attributes }\end{array}$} & \multirow{2}{*}{$\begin{array}{l}\text { Layer of soil } \\
\text { (cm) }\end{array}$} & \multicolumn{3}{|c|}{ Ecological restoration technique } & \multirow[b]{2}{*}{ Native forest } \\
\hline & & $\begin{array}{c}\text { Passive } \\
\text { restoration }\end{array}$ & Tree planting & Nucleation & \\
\hline \multirow{3}{*}{$\mathrm{pH}-\mathrm{H}_{2} \mathrm{O}$} & $0-5$ & 5,5 & 5,4 & 5,4 & 5,2 \\
\hline & $5-10$ & 5,6 & 5,6 & 5,6 & 5,3 \\
\hline & $10-20$ & 5,7 & 5,6 & 5,5 & 5,0 \\
\hline \multirow{3}{*}{ pH-SMP } & $0-5$ & 6,2 & 6,0 & 6,2 & 6,0 \\
\hline & $5-10$ & 6,1 & 6,2 & 6,1 & 6,1 \\
\hline & $10-20$ & 6,3 & 6,3 & 6,3 & 6,1 \\
\hline \multirow{3}{*}{$\operatorname{SOM}(\%)$} & $0-5$ & 4,7 & 4,8 & 5,8 & 7,5 \\
\hline & $5-10$ & 3,6 & 3,6 & 3,9 & 5,3 \\
\hline & $10-20$ & 2,8 & 3,0 & 3,2 & 3,7 \\
\hline \multirow{3}{*}{$\mathrm{P}\left(\mathrm{mg} \mathrm{kg}^{-1}\right)$} & $0-5$ & 3,5 & 3,6 & 3,6 & 2,7 \\
\hline & $5-10$ & 2,2 & 1,4 & 2,4 & 0,6 \\
\hline & $10-20$ & 1,2 & 1,0 & 1,2 & 0,5 \\
\hline \multirow{3}{*}{$\mathrm{K}\left(\mathrm{mg} \mathrm{kg}^{-1}\right)$} & $0-5$ & 396,2 & 245,3 & 316,8 & 207,4 \\
\hline & $5-10$ & 266,9 & 102,2 & 92,3 & 59,1 \\
\hline & $10-20$ & 95,4 & 79,2 & 60,3 & 32,7 \\
\hline
\end{tabular}

$\mathrm{pH}-\mathrm{H}_{2} \mathrm{O}: \mathrm{pH}$ obtained by the mixture of soil and water in the proportion of $1: 1 ; \mathrm{pH}-\mathrm{SMP}: \mathrm{pH}$ obtained by the mixture of soil, water and SMP buffer solution in the proportion of 1:1:0,5; SOM: organic matter of the soil obtained by humid combustion; P: phosphorus extracted by Mehlich-1; K: potassium extracted by Mehlich-1.

Soil basal respiration (SBR) was measured according to Anderson [19]. For this purpose, the duplicate $\mathrm{C}-\mathrm{CO}_{2}$ emission of $50 \mathrm{~g}$ of soil was evaluated and incubated with $10 \mathrm{~mL}$ of $1.0 \mathrm{M}$ sodium hydroxide $(\mathrm{NaOH})$ for four, eight, twelve and sixteen days. The metabolic quotient $\left(q \mathrm{CO}_{2}\right)$ was obtained from the ratio of $\mathrm{C}-\mathrm{CO}_{2}$ 
per $\mathrm{C}_{\mathrm{MIC}}$ unit per time, according to the method described by Anderson [20]. Microbial quotient (MICq) (\%) was estimated from the relationship between $\mathrm{C}_{\mathrm{MIC}}$ and OCC [21].

The spore content analysis followed the wet sieving methodology [22]. To do so, $50 \mathrm{~mL}$ of soil were diluted in $1,700 \mathrm{~mL}$ of water, then decanting the solution for 3 minutes and pouring the supernatant into a 53 $\mu \mathrm{m}$ sieve. Then the residue retained in the sieve was transferred to the centrifuge tube with $60 \%$ and $20 \%$ sucrose solutions, submitted to 3,500 rpm. The supernatant was sieved in $250 \mu \mathrm{m}, 106 \mu \mathrm{m}$ and $53 \mu \mathrm{m}$ mesh for spore separation, then transferred to petri dishes for magnifying.

The obtained data were subjected to analysis of variance and when significant were compared by means of the Scott-Knott test $(p<0.05)$ with the aid of SASM-Agri software.

\section{RESULTS}

Soil organic carbon content (OCC) was significantly higher under nucleation technique, while it did not differ between tree planting and passive restoration (Table 2). On the other hand, the microbial biomass carbon $\left(\mathrm{C}_{\mathrm{MIC}}\right)$ did not differ significantly between the ecological restoration technologies evaluated, indicating that the microbial soil biomass was not influenced by the treatments. In addition, the OCC and $\mathrm{C}_{\text {MIC }}$ of the soil under native forest were, respectively, $50 \%$ and $100 \%$ higher than the soil contents under restoration technologies (Table 2). Accompanying this behaviour, the microbial quotient (MICq), which is a percentage of $\mathrm{C}_{\text {MIC }}$ relative to OCC, also did not differ between ecological restoration technologies and averaged $45 \%$ less than the soil under native forest (Table 2). This indicates that the higher OCC content observed in the soil under the nucleation technique was not enough to positively influence $\mathrm{C}_{\text {MIC }}$ and MICq.

$\mathrm{N}_{\text {MIC }}$ was higher in soil under nucleation and tree planting, differing from soil under passive restoration, but they were all lower than native forest soil, which reached twice the soil $\mathrm{N}_{\text {MIC }}$ content than ecological restoration techniques (Table 2). The behaviour was very similar to the soil $\mathrm{C}_{\text {MIC, }}$ indicating that the accumulation of $\mathrm{N}$ and $\mathrm{C}$ in the microbial biomass is higher in soils with higher OCC content.

Table 2. Organic carbon content (OCC) and microbiological soil attributes after eight years of implantation of the ecological restoration techniques passive restoration; tree planting and nucleation, besides native forest area as reference.

\begin{tabular}{lcccc}
\hline Treatments & OCC & $\mathbf{N}_{\text {MIC }}$ & $\mathbf{C}_{\text {MIC }}$ & MICq \\
\hline & $\mathrm{g} \mathrm{kg}^{-1}$ & $----------\mathrm{mg} \mathrm{kg}^{-1}---------$ & $\%$ \\
Passive restoration & $26,0 \mathrm{c}^{*}$ & $140,6 \mathrm{c}$ & $83,9 \mathrm{~b}$ & $0,32 \mathrm{~b}$ \\
Tree planting & $28,0 \mathrm{c}$ & $270,6 \mathrm{~b}$ & $111,8 \mathrm{~b}$ & $0,39 \mathrm{~b}$ \\
Nucleation & $31,8 \mathrm{~b}$ & $273,6 \mathrm{~b}$ & $111,8 \mathrm{~b}$ & $0,33 \mathrm{~b}$ \\
Native forest & $43,3 \mathrm{a}$ & $442,3 \mathrm{a}$ & $203,0 \mathrm{a}$ & $0,50 \mathrm{a}$ \\
\hline CV (\%) & 9,1 & 29,0 & 20,4 & 22,5 \\
\hline
\end{tabular}

${ }^{*}$ Means followed by the same letters in the column do not differ significantly among themselves under Scott-Knott's test at the level of $5 \%$ of probability. OCC: organic carbon content; $\mathrm{N}_{\text {MIC }}$ : microbial nitrogen; $\mathrm{C}_{\text {MIC: }}$ microbial biomass carbon; MICq: microbial quotient.

Soil basal respiration (SBR) was higher under nucleation technique and evened to the soil contents under native forest (Table 3). SBR followed a similar behaviour to OCC, indicating that the biological activity was higher under soil conditions with higher total carbon content (Table 2). Another analysis that reinforces this statement is the metabolic quotient $\left(\mathrm{qCO}_{2}\right)$, which was inversely proportional to SBR of soil under nucleation. None of the restoration techniques achieved the native forest soil $\mathrm{qCO}_{2}$ content (Table 3).

The fungal spore content, which is an indicator of soil microbial activity, was higher in the soil under the nucleation technique, differing significantly from the other techniques, but these levels were still lower than in native forest (Table 3). These data have a behaviour like OCC and inversely proportional to $\mathrm{qCO}_{2}$, which indicates that microbial activity is higher in soil under nucleation compared to other restoration techniques.

Of the six microbiological attributes evaluated, only one (SBR) the soil under one of the techniques of restoration were equivalent to the soil under native forest. 
Table 3 - Soil basal respiration (SBR), metabolic quotient $\left(\mathrm{qCO}_{2}\right)$ and spores of soil fungi after eight years of implantation of the ecological restoration techniques passive restoration; tree planting and nucleation, besides native forest area as reference.

\begin{tabular}{lccc}
\hline Treatments & SBR & $\mathrm{qCO}_{2}$ & SPORES \\
\hline & ${\mathrm{mg} \mathrm{C}-\mathrm{CO}_{2} \mathrm{~kg}^{-1} \mathrm{~h}^{-1}}$ & $\mathrm{mg} \mathrm{C}-\mathrm{CO}_{2} \mathrm{~g}^{-1} \mathrm{CMIC}_{\mathrm{MI}^{-1}} \mathrm{~h}^{-1}$ & Un $50 \mathrm{~mL} \mathrm{solo-1}^{-1}$ \\
Passive restoration & $280,0 \mathrm{~b}$ & $8,7 \mathrm{a}$ & $434,2 \mathrm{c}$ \\
Tree planting & $269,6 \mathrm{~b}$ & $8,0 \mathrm{a}$ & $381,0 \mathrm{~d}$ \\
Nucleation & $317,3 \mathrm{a}$ & $6,6 \mathrm{~b}$ & $559,0 \mathrm{~b}$ \\
Native forest & $356,5 \mathrm{a}$ & $4,8 \mathrm{c}$ & $590,7 \mathrm{a}$ \\
\hline CV (\%) & 10,5 & 19,0 & 3,1
\end{tabular}

${ }^{*}$ Means followed by the same letters in the column do not differ significantly among themselves under Scott-Knott's test at the level of $5 \%$ of probability. SBR: soil basal respiration; $\mathrm{qCO}_{2}$ : metabolic quotient; Spores: spores of soil fungi.

\section{DISCUSSION}

The higher content of OCC in the soil under nucleation contributed to higher SBR and, consequently, lower $\mathrm{qCO}_{2}$. The release of $\mathrm{CO}_{2}$ occurs by the degradation of organic matter and tends to be higher with the increase of its content, and the SBR is reflected in the speed of degradation of organic matter [5]. Higher soil $\mathrm{SBR}$ values under less impacting systems were also detected in Silva's work [23]. Already the lowest $\mathrm{qCO}_{2}$ in the soil under nucleation, according to Yada [24], is found in areas that are in balance and with a higher energy accumulation. When the area becomes more balanced microbial biomass becomes more efficient, less $\mathrm{CO}_{2}$ is lost by basal respiration and more carbon are incorporated into the microbial tissues, which causes a decrease in $\mathrm{qCO}_{2}$ [25]. Nucleation's ability to stimulate microbial biomass respiratory activity at the same level as the soil under native forest indicates that this technique is allowing the environment to acquire characteristics of a preserved area.

Similarly, the higher fungal spore content in soil under nucleation is another indicator of higher biological activity. This higher content may be related to the predominance of cowpea (Cajanus cajan) observed by Trentin [6] in this experiment, which was sown in 24 cores per plot to improve soil quality due to its nitrogen fixation capacity, and for being a species that has a short life cycle. Klippel [26] found that planting leguminous species to recover degraded areas provides better quality senescent material with low $\mathrm{C} / \mathrm{N}$ ratio. This may have contributed to the increased biological activity in nucleation technology. However, Bianchi [28] found that the use of different proportions of forest legumes in the revegetation did not promote changes in the spore density of arbuscular mycorrhizal fungi.

The technology of tree planting did not differ from nucleation in three of the six evaluated microbiological attributes ( $\mathrm{N}_{\text {MIC }}, \mathrm{C}_{\mathrm{MIC}}$ and MICq), however, had lower OCC content and lower microbial activity. According to Trentin [6], who evaluated this experiment, tree planting technology was inefficient in regenerating the area between the planted seedlings, due to the need for maintenance with mowing to ensure their survival and the large number of seedlings introduced affected natural directions of succession. In addition, this treatment requires greater budget and involvement, due to the costs of seedlings and the silvicultural procedures required to maintain the area until the age of three. Intensive management in this ecological restoration technology contributed to lower carbon addition to the soil and, consequently, lower microbial activity. Soils under areas without anthropic interference are favored by vegetation cover, which provides the accumulation of organic matter, causing the microbial community to increase [28].

Passive restoration technology presented the worst results in four of the six evaluated microbiological attributes ( $\mathrm{N}_{\mathrm{MIC}}, \mathrm{SBR}, \mathrm{qCO}_{2}$ and fungal spores), besides having the lowest content of OCC, indicating a limitation of this technique to improve soil microbiological attributes. Evaluating this same experiment, Trentin [6] found that passive restoration is a good technology option because it has a low implantation cost and that its diversity of plant species did not differ from nucleation. However, according to data from the present study, passive restoration was less efficient than nucleation to improve soil microbiological attributes. This makes the nucleation technique more advantageous over passive restoration and tree planting. 
Among the three ecological restoration technologies evaluated, only nucleation obtained two (SBR and $\mathrm{qCO}_{2}$ ) of the six evaluated soil microbiological attributes equal to those obtained in the soil under native forest. The higher levels of $\mathrm{C}_{\text {MIC }}, \mathrm{N}_{\text {MIC }}, \mathrm{MICq}$ and fungal spores found in the soil under native forest are justified by the higher OCC content and quality, MICq which indicates the quality of soil organic matter [4]. In native forest areas there is a higher volume of litter and roots, which promote increased species diversity [29], organic matter content and nutrient availability [7].

Lower values of $\mathrm{qCO}_{2}$ of the soil under native forest in relation to the ones under restoration techniques are compatible to the ones observed by Zaninetti [30], where the author observed higher $\mathrm{qCO}_{2}$ and lower contents of $\mathrm{OCC}$ and $\mathrm{C}_{\mathrm{MIC}}$ in areas of forestry reposition comparatively to primary forests. In this sense, eight years of implementation of ecological restoration technologies have not yet been enough to significantly improve soil microbiological attributes, requiring new evaluations over time.

In recent years, many studies have been carried out in Brazil on microbiological attributes in soils under native forests $[4,23,24,30]$. When comparing them with the data from the present study, it appears that CMIC, $\mathrm{MICq}$, basal respiration and $\mathrm{qCO}_{2}$ were worse in the evaluated soil under native forest (Atlantic Forest) than under Cerrado forest [23] and the Amazon forest [30]. However, the lack of standardization of methods of analysis and misunderstandings in the calculation of indexes such as $\mathrm{qMIC}$ and $\mathrm{qCO}_{2}$ in published articles hindered a more in-depth comparison of microbiological attributes between Brazilian forests or biomes. This lack of methodological standardization is a problem that must be debated by the scientific community of Soil Science.

\section{CONCLUSION}

Nucleation technology can restore soil microbiological attributes but has not yet reached the conditions of a natural environment. Passive restoration is not a good technology for restoring soil microbiological attributes.

The higher contents of $\mathrm{C}_{\mathrm{MIC}}, \mathrm{N}_{\mathrm{MIC}}, \mathrm{OCC}, \mathrm{MICq}$ and fungal spores in the soil under native forest compared to ecological restoration technologies indicate that eight years of adoption of these techniques have not been enough to fully recover soil microbiological activity.

\section{REFERENCES}

1. Wadt PGS, Pereira JES, Gonçalves RC, Souza CB, Alves LS. Práticas de Conservação do Solo e Recuperação de Áreas Degradadas. Rio Branco (AC): Embrapa Acre; 2003. 29 p.

2. Freitas L, Oliveira IA, Silva LS, Frare JCV, Filla VA, Gomes RP. Indicadores da qualidade química e física do solo sob diferentes sistemas de manejo. Rev. Unimar Ciências. 2017;26(2):08-25.

3. Alves LF, Metzger JP. A regeneração florestal em áreas de floresta secundária na Reserva Florestal do Morro Grande, Cotia, SP. Biota Neotrop. 2006 Mai;6(2):1-26. doi:10.1590/S1676-06032006000200005

4. Novak E, Carvalho LA, Santiago EF, Brumatti AV, Santos LL, Sales LC. Variação temporal dos atributos microbiológicos do solo sob diferentes usos. Rev. Ciênc. Agrár. 2018 Sep;41(3):603-11. doi:10.19084/RCA17300

5. Santos AC, Silva IF, Lima JRS, Andrade AP, Cavalcante VR. Gramíneas e leguminosas na recuperação de áreas degradadas: efeito nas características químicas de solo. R. Bras. Ci. Solo. 2001 Mai;25(4):1063-71 doi:10.1590/S0100-06832001000400028.

6. Trentin BE, Estevan DA, Rossetto EFS, Gorenstein MR, Brizola GP, Bechara FC. Restauração florestal na Mata Atlântica: passiva, nucleação e plantio de alta diversidade. Ci. Fl. 2018 Jan/Mar;28(1):160-74.

7. Piaia BB, Rovedder APM, Costa AM, Felker RM, Piazza EM, Stefanello MM. Transposição do banco de sementes para restauração ecológica da floresta estacional no Rio Grande do Sul. Agrária. 2017 Ajpr;12(2):227-35. doi:10.5039/agraria.v12i2a5442.

8. Evangelista CR, Partelli FL, Ferreira EP, Pires FR. Atributos microbiológicos do solo na cultura da cana-de-açúcar sob manejo orgânico e convencional. Semina. 2013 Jul/Aug;34(4):1549-62. doi:10.5433/16790359.2013v34n4p1549.

9. Peña MLP, Marques R, Jahnel MC, Anjos A. Respiração microbiana como indicador da qualidade do solo em ecossistema florestal. Rev. Floresta. 2005 Jan/Apr;35(1):117-27.

10. Alvares CA, Stape JL, Sentelhas PC, Gonçalves JLM, Sparovek G. Köppen's climate classification map for Brazil. Meteorol. Z. 2013 Jan;22(6):711-28. doi:10.1127/0941-2948/2013/0507

11. Gandolfi S, Rodrigues RR. Manejo ambiental e restauração de áreas degradadas. São Paulo (Brasil): Fundação Cargill; 2007. 190 p.

12. Reis A, Bechara FC, Tres DR. Nucleation in tropical ecological restoration. Sci. Agric. 2010 Mar/Abr;67(2):244-50. doi:10.1590/S0103-90162010000200018 
13. Bechara FC, Dickens SJ, Farrer EC, Larios L, Spotswood EN, Mariotte P, Suding KN. Neotropical rainforest restoration: comparing passive, plantation and nucleation approaches. Biodivers. Conserv. 2016 Jul;25:2021-34. doi:10.1007/s10531-016-1186-7

14. Tedesco MJ, Gianello C, Bissani CA, Boahnen H, Volkweiss SJ. Análise de solo, plantas e outros materiais. $2^{\mathrm{a}}$ ed.; Publisher: Porto Alegre: UFRGS, Brasil, 1995. 174 p.

15. Yeomans JC, Bremner JM. A rapid and precise method for routine determination of organic carbon in soil. Commun. Soil. Sci. Plant Anal.1988;19(13):1467-76. Doi:10.1080/00103628809368027

16. Silva EE, Azevedo PHS, De-Polli H. Determinação do Carbono da Biomassa Microbiana do Solo. Comunicado técnico 98. Seropérica (RJ): Embrapa Agrobiologia; 2007. 6p.

17. Silva EE, Azevedo PHS, De-Polli, H. Determinação do Nitrogênio da Biomassa Microbiana do Solo. Comunicado técnico 96. Seropérica (RJ): Embrapa Agrobiologia; 2007. 6 p.

18. Vance ED, Brookes PC, Jenkinson DS. An extraction method for measuring soil microbial biomass C. Soil Biol Biochem. 1987;19(6):703-07. doi:10.1016/0038-0717(87)90052-6.

19. Anderson JPE. Soil respiration. In: Page AL, editor. Methods of soil analysis. Vol 2, Chemical and microbiological properties, 2nd ed. Madison; 1982. p. 831-71.

20. Anderson $\mathrm{TH}$, Domsch $\mathrm{KH}$. The metabolic quotient for $\mathrm{CO}_{2}\left(\mathrm{qCO}_{2}\right)$ as a specific activity parameter to assess the effects of environmental conditions, such as $\mathrm{pH}$, on the microbial biomass of forest soils. Soil Biol Biochem. 1993 Mar;25(3):393-405. doi:10.1016/0038-0717(93)90140-7

21. Sparling GP, West AW. A direct extraction method to estimate soil microbial C: calibration in situ using microbial respiration and 14C labelled cells. Soil Biol Biochem. 1988;20(3):337-43. doi:10.1016/0038-0717(88)90014-4

22. Gerdemann JW, Nicolson THS. Spores of mycorrhizal Endogone species extracted from soil by wet sieving and decanting. Trans. Br. Mycol. Soc. 1963 Jun;46(2):235-44.

23. Silva RR, Silva MLN, Cardoso EL, Moreira FMS, Curi N, Alovisi AMT. Biomassa e atividade microbiana em solo sob diferentes sistemas de manejo na região fisiografica Campos das Vertentes-MG, Rev. Bras. Ciênc. Solo. 2010 Sep;34(5):1585-92. doi:10.1590/S0100-06832010000500011

24. Yada MM, Mingotte FLC, Melo WJ, Melo G.P.; Melo VP, Longo RM, Ribeiro Al. Atributos Químicos e Bioquímicos em Solos Degradados por Mineração de Estanho e em Fase de Recuperação em Ecossistema Amazônico. Rev. Bras. Ciênc. Solo. 2015 Mai/Jun;39(3):714-24. doi:10.1590/01000683rbcs20140499

25. Ferreira EP, Stone LF, Martin-Didonet, CCG. População e atividade microbiana do solo em sistema agroecológico de produção. Rev. Ciênc. Agron. 2017 Jan/Mar;48(1):22-31. doi:10.5935/1806-6690.20170003

26. Klippel VH, Pezzopane JEM, Caldeira MVW, Silva GF, Castro KC. Acúmulo de serapilheira e nutrientes em área com diferentes metodologias de Restauração Florestal, Com. Sci. 2016 Apr/Jun;7(2):241-50. doi:10.14295/CS.v7i2.521

27. Bianchi MO, Scoriza RN, Silva EMR, Campello EFC, Correia MEF. Influência da proporção de leguminosas florestais sobre a comunidade de fungos micorrízicos em área revegetada. Rev. Agrogeoamb. 2016 Dec;8(4):2332. doi:10.18406/2316-1817v8n42016890

28. Carvalho $\mathrm{F}$ de. Atributos Bioquímicos como indicadores da qualidade de solo em Florestas de Araucária angustifólia [master's thesis]. Piracicaba (SP): Universidade de São Paulo, Escola Superior de Agricultura "Luiz de Queiroz", Mestrado em Ecologia de Agroecossitemas; 2005. 95 p.

29. Couto WH, Anjos LHC, Pereira MG, Guareschi RF, Assunção SA, Wadt PGS. Carbono, Nitrogênio, Abundância Natural de $\triangle 13 \mathrm{C}$ e $\triangle 15 \mathrm{~N}$ do Solo sob Sistemas Agroflorestais. Floresta Ambient. 2017 Aug;24:1-8. Doi:10.1590/2179-8087.117614

30. Zaninetti RA, Moreira A, Moraes LAC. Atributos físicos, químicos e biológicos de Latossolo Amarelo na conversão de floresta primária para seringais na Amazônia. Pesq. Agropec. Bras. 2006 Sep;51(9):1061-8. doi:10.1590/S0100-204X2016000900005

(C) 2020 pelos autores. Submetido para possível publicação de acesso livre, nos termos e condições do Creative Commons Attribution (CC BY NC) licença (https://creativecommons.org/licenses/by-nc/4.0/). 